\title{
TEMPORARY INTRINSICS AND CHRISTOLOGICAL PREDICATION
}

\author{
Timothy Pawl
}

This is a penultimate manuscript, and not a final version, of a forthcoming article in Oxford Studies in Philosophy of Religion. As such, please do not cite this version; cite the official version, due out in OSPR VII in 2015.

\section{INTRODUCTION}

One standard problem in contemporary metaphysical literature is the problem of temporary intrinsics. David Lewis (2001, 203-204) introduces the problem in question format as follows:

Persisting things can change their intrinsic properties. For instance shape: when I sit, I have a bent shape; when I stand, I have a straightened shape. Both shapes are temporarily intrinsic properties; I have them only some of the time. How is such change possible?

How can one thing - say, a woman who persists over time - be both bent and straight? One common opening move in response to this problem is to claim that the woman is not both bent and straight in the same exact way, since she is straight at one time, bent at another. It is due to having the intrinsic properties at different times, however one spells that out philosophically, that this problem earns the name "the problem of temporary intrinsics."

One standard problem in Christological literature is a problem we might call the problem of natural intrinsics. Richard Cross $(2011,453)$ introduces the problem in question format as follows:

[T] he fundamental philosophical problem specific to the doctrine is this: how is it that one and the same thing could be both divine (and thus, on the face of it, necessary, and necessarily omniscient, omnipotent, eternal, immutable, impassible, and impeccable) and human (and thus, on the face of it, have the complements of all these properties)?

How can one thing - the God-man, Jesus Christ - be both impassible and passible (or necessarily omnipotent and not necessarily omnipotent, or...)? One common opening move in response to this problem is to claim that the God-man is not both passible and impassible in the same exact way, since he is passible according to his human nature, 
and impassible according to his divine nature. It is due to having the intrinsic properties according to different natures, however one spells that out philosophically, that this problem could be dubbed "the problem of natural intrinsics."

I believe that there is a deep, unnoticed analogy between the problem of temporary intrinsics and the problem of natural intrinsics. ${ }^{1}$ The literature on temporary intrinsics contains many carefully worked out philosophical responses to the problem. The Christological literature would be helped by a study of analogous answers to the fundamental problem Cross expresses. Likewise, there is at least one answer to the problem of natural intrinsics that is carefully worked out in that literature, and applicable to the problem of temporary intrinsics, though I know of no one who employs it. ${ }^{2}$

In this article, I present the main answers to the problem of temporary intrinsics, and then apply analogous answers to the problem of natural intrinsics. A full analysis of the viability of the analogous answers is far too long to include here, but much of this analysis has been done elsewhere. ${ }^{3}$

In Section II I present the problem of temporary intrinsics in detail. Then in Section III I present multiple solutions that have been offered to the problem. In Section IV I present the problem of natural intrinsics in detail. Then in Section V I present multiple solutions one can offer to that problem based on the solutions to the problem of temporary intrinsics canvassed in Section III.

\section{THE PROBLEM OF TEMPORARY INTRINSICS}

Douglas Ehring $(1997,254)$ presents the problem of temporary intrinsics as follows:

[I]f object $o$ is wholly present at both $t$ and $t^{\prime}$ (o at $t$ is identical with $o$ at $t^{\prime}$ ), and $o$ has $P$ (an intrinsic property) at $t$, but $o$ has property $Q$ at $t^{\prime}$, where $Q$ is incompatible with

\footnotetext{
${ }^{1}$ One initial disanalogy, at least according to the proponent of divine simplicity, is that God does not bear properties, and so however one spells out the analogy, it ought not be in terms of properties. In this paper, I will assume that we can speak of God bearing properties. If this is unacceptable to the divine simplicity theorist, she is encouraged to employ whatever strategy she normally employs when talk of the divine bearing properties needs to be paraphrased away. For help on this front, see the work of Jeffrey Brower (Bergmann and Brower 2006; Brower 2008; Brower 2009) and James Dolezal (Dolezal 2011).

2 That response is the relative identity response presented by van Inwagen $(1988 ; 1998)$, discussed in section $\mathrm{V}$ below.

${ }^{3}$ See XXXX.
} 
$P$, then $o$ is both $P$ and $Q$, given the indiscernibility of identicals.

The main assumptions here are that the bearers of the intrinsic properties, $P$ and $Q$, are one and the same, that the intrinsic properties themselves are incompatible, and the indiscernibility of identicals - the claim that if $\mathrm{x}$ and $\mathrm{y}$ are identical, then, for any property, $\mathrm{P}, \mathrm{x}$ has $\mathrm{P}$ if and only if $\mathrm{y}$ has $\mathrm{P} .4$

We might present the assumptions made in the problem of temporary intrinsics as follows:

The Identity Assumption (IdA):

The Incompatibility Assumption (InA):

The Indiscernibility of Identicals (II):
The subjects of the properties in question are identical. 5

The properties in question are incompatible intrinsic properties.

For any $x$ and any $y$, if $x=y$, then, for any property, $\mathrm{P}, \mathrm{P}$ is had by $x$ iff $\mathrm{P}$ is had by $y$.

One final assumption, unstated but surely intended, is that nothing can be the subject of two incompatible properties, which we might understand as follows:

No Incompatible Properties (NIP): $\quad \begin{aligned} & \text { Nothing can have incompatible } \\ & \text { properties. }\end{aligned}$

These four assumptions, together with any of very many pairs of predications we are prone to accept, entail a contradiction (or at least, allegedly entail a contradiction).

We might put the problem of temporary intrinsics together as a reductio ad absurdum, as follows: 6

${ }^{4}$ What is an intrinsic property? Here are three analyses quoted from Weatherson and Marshall (2013): " $F$ is intrinsic iff $F$ never differs between duplicates"; "Being $F$ is an intrinsic property iff, necessarily, anything that is $F$ is $F$ in virtue of the way it itself, and nothing wholly distinct from it, is"; " $F$ is an intrinsic property iff, necessarily, for any $x$, an ascription of $F$ to $x$ is entirely about how that thing and its parts are, and not at all about how things wholly distinct from it are." Any one of them would be sufficient for my purposes here.

${ }^{5}$ I write of the subjects and properties "in question" rather than particular subjects and particular properties, since I want the assumptions to be general assumptions for any problem of temporary intrinsics, and not assumptions about the individuals discussed in some particular example; e.g. the object, $o$, and the intrinsic properties, $P$ and $Q$, in Ehring's example.

${ }^{6}$ Trenton Merricks $((1994,168)$ followed by Craig $(1998,122))$ presents the argument as a Reductio of similar form. Merricks provides as premises the following: "(1) $O$ at $t$ is identical with $O$ at $t^{* \prime \prime}$; "(2) $O$ at $t$ is bent"; "(3) $O$ at $t^{*}$ is not bent"; "(4) If $O$ at $t$ is identical with $O$ at $t^{*}$, then $O$ at $t$ is $F$ if and only if $O$ at $t^{*}$ is $F . "$ He concludes that "(5) $O$ at $t$ is bent and is not bent." 
1t. Louise at $t_{1}$ is straight.

$2 t$. Louise at $t_{2}$ is bent.

3t. Louise at $t_{1}$ is identical with Louise at $t_{2}$.

4t. Straight and bent are incompatible intrinsic properties.

5t. Nothing can be both bent and straight.

6t. Louise at $t_{1}$ is bent.

$7 \mathrm{t}$. Louise at $\mathrm{t}_{1}$ is both bent and straight.

8t. Contradiction!
(Assume.)

(Assume.)

(From IdA.)

(From InA.)

(From NIP and 4t.)

(From 2t, 3t, and II.)

(From $1 \mathrm{t}$ and 6t.)

(From $5 \mathrm{t}$ and $7 \mathrm{t}$.)

Here we have derived a contradiction from the four assumptions listed above - the Identity Assumption, the Incompatibility Assumption, the Indiscernibility of Identicals, and No Incompatible Properties - along with the two predications that started the reductio - premises $1 \mathrm{t}$ and $2 \mathrm{t}$. We must, then, deny or distinguish at least one member of this inconsistent hexad, or reject an inference made between $3 \mathrm{t}$ and $8 \mathrm{t}$.

\section{SOLUTIONS TO THE PROBLEM OF TEMPORARY INTRINSICS}

In this section I canvas the solutions to the problem of temporary intrinsics on offer in the contemporary metaphysical literature. I present each response, along with the premise(s) or inference(s) the response denies.

The most common initial reaction to this problem is to claim that while something cannot have two incompatible intrinsic properties at the same time, nothing bars one and the same thing from having two incompatible intrinsic properties at different times. This initial reaction is on the right track, but it is insufficient to answer the argument presented above. What we need is some way of denying some premise or inference of the problem of temporary intrinsics, and this initial reaction, by itself, provides no particular way of doing so.

One helpful way to work through different modes of understanding this initial reaction is to consider different ways that the temporal modifier "at $t_{n}$ " might be understood to augment the premises of the argument. By my lights, there are at least six ways the modifier might modify a premise. First, note an initially plausible disjunction: if the modifier augments the premise, it augments the premise either by being appended as a modifier to the premise (or some part thereof), or not by being so appended, but by

His argument employs the Identity Assumption, (1), and the Indiscernibility of Identicals, (4), as well as the two problematic predications, (2) and (3). He doesn't explicitly employ the Incompatibility Assumption or No Incompatible Properties, which seems entirely reasonable, given his choice of properties in his example (e.g., bent, not bent.). I include both of those assumptions explicitly, since there are some responses to the problem of natural intrinsics which deny them. One can see these assumptions in the presentation of Tobias Hansson $(2007,266)$ as well. 
signaling that some part of the premise ought to be understood in a particular way. Consider the first disjunct.

If the modifier is appended to the premise as a modification, I see five ways it might be so appended. It might modify the whole predication (the whole assertion, " $x$ is $\left.F^{\prime \prime}\right)$, it could modify the subject alone $(x)$, it could modify the predicate alone (F), it could modify the copula binding the subject to the predicate (is), or it could modify something not explicitly stated in the premise, but tacitly assumed.7

Letting the name " 1 " refer to Louise, and the predicates " $\mathrm{S}$ " and " $\mathrm{B}$ " name the properties Straight and Bent, respectively, we can represent the first four ways as follows, hyphenating the temporal modifier into the relevant parts of the predication in the last three options: ${ }^{8}$

\begin{tabular}{|c|c|c|}
\hline Assertion (A): & at $t_{1}, l$ is $S$ & at $t_{2}, l$ is $B$ \\
\hline Subject (S): & l-at- $t_{1}$ is $S$ & l-at- $t_{2}$ is $B$ \\
\hline Predicate (P): & $l$ is $S$-at- $t_{1}$ & $l$ is $B$-at- $t_{2}$ \\
\hline Copula (C): & $l$ is-at- $t_{1} S$ & l is-at- $t_{2}$ B. ${ }^{9}$ \\
\hline
\end{tabular}

The fifth way, the way of modifying some tacit thing assumed but unstated, is difficult to represent without a concrete case. I will consider such a case in Section V when discussing the relative identity solution to the problem of natural intrinsics. Until then, I will set that way of augmenting the predication to one side.

Consider the second disjunct of the initially plausible disjunction. The modifier might not be appended into the premise as a modification at all. It might, instead, be used to note that a particular part of the premise ought to be understood in a certain way that is not reflected in the current formulation of the premise. The only example of this response that I know of in the literature on the problem of temporary intrinsics is

${ }^{7}$ Let the term "predication" refer to statements of the form "s is F"; for instance, "Kathryn is courageous." 7 Let the term "predicate" refer to the term that is said of the subject of the sentence. In the previous example, the predicate is "courageous." Finally, the "is" in a predication is not part of the predicate. Rather, it is a third part of the predication, which I will call the "copula," following Aristotelian logic (Cf. Cross 2005, 186).

8 I get the idea for hyphenating like this from Lowe $(1988,73 ; 2002,43-49)$.

${ }^{9}$ It seems to me that Sally Haslanger $(1989,121)$ views these four methods of temporal modification as the options available as well. She writes "Lowe's comments suggest two ways to incorporate temporal elements into one's semantics: the first is to leave temporal elements out of propositions and instead to evaluate propositions with respect to times (just as one evaluates propositions with respect to worlds) [(A)]; the second is to include temporal elements in the proposition without incorporating them $[(C)]$ into the semantical value of the predicate $[(\mathrm{P})]$ (or the subject $[(\mathrm{S})]) . "$ 
the Serious Tenser response, which claims that at least one of the premises ought to have its verb tense changed. In such a case, the clause "at $t_{n}$ " is included, says the serious tenser, to help determine which verb tenses are correct.

In what follows, I will discuss responses that understand the "at $t_{n}$ " clause in each of these ways, in each case pointing out which step of the argument the response denies, and which extant solutions take this approach. I will begin with the second disjunct.

\section{Taking Tense Seriously ( $\mathrm{T}$ )}

One might take the temporal modifier, not as something appended in some way into the premise, but rather as expressing how one ought to understand the parts of the premise that are already there. The main way of doing this in the literature is to be a "Serious Tenser," one who takes tense to be an irreducible part of predication. ${ }^{10}$

If we understand the temporal modifier, together with our knowledge of when it is, as telling us how we ought to understand the tenseless verbs in the predications of $1 \mathrm{t}$ and $2 t$, then some of the premises of the problem should be revised to make this understanding explicit. Assume, for the moment, that $t_{1}$ is a past time, and $t_{2}$ is the present. Then premises $1 \mathrm{t}$ and $2 \mathrm{t}$ ought to be rephrased as follows:
$1 \mathrm{t}(\mathrm{T})$. Louise was straight.
(Assume.)
$2 t(T)$. Louise is bent.
(Assume.)

How ought we to understand premise $3 t$, which is a claim about the identity of something over time, and not a predication? Trenton Merricks $(1994,176)$, a proponent of the serious tenser strategy, says
"O at $\mathrm{t}$ is identical with $\mathrm{O}^{*}$ at $\mathrm{t}^{* \prime}$ amounts to the claim that $\mathrm{O}$ is identical with $\mathrm{O}^{*}$ (and, of course, is self-identical) and exists at $t$ and $t^{*} \ldots$ " $\mathrm{O}$ at $\mathrm{t}$ is identical with $\mathrm{O}$ at $\mathrm{t}^{\star \prime}$ " can be read "There is one object, $\mathrm{O}$, and that object exists at $\mathrm{t}$ and $\mathrm{t}^{*} . "$

We might follow Merricks here and understand 3t as saying, "There is one object, Louise, and she exists at $t_{1}$ and $t_{2 .}$ " This, claim, though, doesn't take tense seriously. Better, I think, to tense the verb "exists," depending on when the premise is uttered. Assuming, for the moment, that the time is $t_{2}$, we could present $3 t$ as:

$3 t(T)$. There is one object, Louise, and she existed at $t_{1}$ and exists at $\mathrm{t}_{2}$.

(From IdA.)

\footnotetext{
10 See Zimmerman (2005) for a discussion of serious tensing.
} 
Premises $4 \mathrm{t}$ and $5 \mathrm{t}$ remain the same and go unquestioned according to this response. $6 \mathrm{t}$, the claim that Louise at $t_{1}$ is bent, turns out to be true but unproblematic, on the assumption that the definite description "Louise at $t_{1}$ " names Louise and says of her that she existed at $t_{1}$ (as Merricks $(1994,175)$ understands the phrase); the person identical with that person (the person existing now at $t_{2}$, who did exist at $t_{1}$ ) is bent. We might present the premise as follows:

$6 t(T)$. Louise is bent and Louise existed at $t_{1}$.

(From 2t, 3t, and II.)

The problem for the problem, according to the proponents of serious tensing, is that $7 \mathrm{t}$ does not follow from $1 \mathrm{t}$ and $6 \mathrm{t}$, properly understood. For $7 \mathrm{t}$ does not take into account the irreducible tense of the conjuncts that it conjoins. The closest $7 \mathrm{t}$ could come to a contradiction would be, according to the serious tenser:

$7 \mathrm{t}(\mathrm{T})$. Louise is bent and was straight.

(From $1 \mathrm{t}(\mathrm{T})$ and $6 \mathrm{t}(\mathrm{T})$.)

That claim, though, entails no contradiction when conjoined with $5 t$ - nothing, not even Louise, is both bent and straight. And so no contradiction is derived at step 8t.

This response, then, understands the temporal modifier, "at $t_{n}$," as expressing how one ought to understand the "is" in the premises. It claims that at least one of the initial predications ( $1 \mathrm{t}$ or $2 \mathrm{t}$ ) is false, and that, when it is revised so as to make it true, $7 \mathrm{t}$ does not follow. Rather, $7 \mathrm{t}(\mathrm{T})$ follows, which does not yield a contradiction when conjoined with $5 \mathrm{t}$, contra $8 \mathrm{t}$. A common example of this sort of response is Presentism, the claim that, necessarily, for anything that exists at any time, it exists at the present.11

Instead of understanding the temporal modifier as expressing how to understand the stated verb, as the serious tenser solution does, one could take the modifier as being added into the predication as modifying either the whole predication or a part of it. The following four solutions are all instances of taking the modifier as indexing some part of the predication.

Modification of the Whole Assertion (A)

One might take the temporal modifiers to modify the entire predication. This is what Sally Haslanger calls the first way of incorporating temporal elements into semantics (the second way is (C) below). She writes $(1989,121)$ that this first way

\footnotetext{
${ }^{11}$ I do not mean to imply here that presentists must employ this response, or that no nonpresentist can employ this response.
} 
leave[s] temporal elements out of propositions and instead ... evaluate[s] propositions with respect to times (just as one evaluates propositions with respect to worlds) ...

Treating time as part of the circumstances of evaluation (as in the first suggestion) offers a temporalist view of propositions such that propositions can change truth-value from time to time.

On this view, the temporal modifier is a circumstance by which we evaluate the truth of the proposition. In that respect, it functions similarly to the "in St. Paul" of the following sentence: "In St. Paul, it is snowing." We evaluate the truth of that claim by considering what the weather is like in St. Paul, and not by considering what it is like where we are standing (unless, of course, we happen to be lucky enough to be standing in St. Paul). If we understand the temporal modifier to modify the whole assertion, then some of the premises of the problem should be revised to make this understanding explicit. For instance, $1 \mathrm{t}$ and $2 \mathrm{t}$ should read:

$1 \mathrm{t}(\mathrm{A}) . \quad$ At $\mathrm{t}_{1}$, "Louise is straight" is true. (Assume.)

$2 t(A)$. At $t_{2}$, "Louise is bent" is true.

(Assume.)

Premise 3t might be put as follows:

$3 t(A)$. At $t_{1}$ and at $t_{2}$, Louise is identical with Louise.

(From IdA.)

Again, premises $4 \mathrm{t}$ and $5 \mathrm{t}$ get a pass. $6 \mathrm{t}$, though, is problematic.

If we leave 6t unmodified, it no longer even has the appearance of following from the newly modified premises. If, then, we modify $6 t$ in the same way we have modified the previous premises, we get:

6t(A). At $t_{1}$, "Louise is bent" is true.

(From 2t(A), 3t(A), and II.)

$6 t(A)$, though, faces two difficulties. First, it does not follow from the premises cited as its evidence. Second, it is false, given $1 \mathrm{t}(\mathrm{A}), 4 \mathrm{t}$, and $5 \mathrm{t}$. Consider these difficulties in order.

First, 2t(A), 3t(A), and II do not entail $6 \mathrm{t}(\mathrm{A}) .2 \mathrm{t}(\mathrm{A})$ tells us a certain predication is true of Louise at $t_{2} ; 3 t(A)$ tells us that the proposition, Louise is identical with Louise is true at two times; and the indiscernibility of identicals tells us that in her case, since Louise is self-identical, any property she has is a property she has. These three claims do not yield the conclusion that she is bent at an earlier time. 
Second, given the truth of premises $1 \mathrm{t}(\mathrm{A}), 4 \mathrm{t}$, and $5 \mathrm{t}, 6 \mathrm{t}(\mathrm{A})$ cannot be true. Given $1 \mathrm{t}(\mathrm{A})$, "Louise is straight" is true at $\mathrm{t}_{1}$. But, given $4 \mathrm{t}$ and $5 \mathrm{t}$, for any time, if "Louise is straight" is true at that time, then it is false that "Louise is bent" is true at that time. So it is false that, at $t_{1}$, "Louise is bent" is true. So $6 t(A)$ is false.

This response, then, is similar to the serious tensing response, insofar as it solves the problem by rewording at least one initial predication and noting that, given the new wording, a later inference is faulty. But it differs insofar as it allows tenseless predications, unlike the serious tenser view, and it targets a different inference in the argument.

This response understands the temporal modification as a modification of the whole assertion (A), it rewords the initial predications, resulting in an infelicitous inference from $2 t(A), 3 t(A)$, and II to $6 t(A)$, and one common example of this response is Haslanger's first adverbial account, wherein the times are taken to be circumstances for evaluating the truth-value of propositions. ${ }^{12}$

\section{Modification of the Subject (S)}

One might take the temporal modifiers to modify the subject of the predication.

In such a case, they function in a way similar to the modifiers in the following examples: "the road at the intersection with Grand Ave is bumpy"; "the first third of the stick is painted." In such predications, the subject of the predication is modified; it is a particular part of the subject that is the subject of the predication. For instance, it is that part of the road where it intersects with Grand Ave - and not, say, where the same road intersects with Summit Ave - that the road is bumpy.

If we understand the temporal modifier to modify the subject, the premises of the problem are stated in a way amenable to a solution. Making the representation explicit, the first three premises would appear like so:

$\begin{array}{lll}1 \mathrm{t}(\mathrm{S}) . & \text { Louise-at- } \mathrm{t}_{1} \text { is straight. } & \text { (Assume.) } \\ 2 \mathrm{t}(\mathrm{S}) . & \text { Louise-at- } \mathrm{t}_{2} \text { is bent. } & \text { (Assume.) } \\ 3 \mathrm{t}(\mathrm{S}) . & \text { Louise-at- } \mathrm{t}_{1} \text { is identical with Louise-at- } \mathrm{t}_{2} . & \text { (From IdA.) }\end{array}$

There is something, Louise-at- $t_{1}$, that is straight. There is another thing, Louise-at- $t_{2}$, that is bent. Just like there is a part of the road that is bumpy, and a part that is smooth. Taking the temporal modifier to modify the subject, we can see the culprit: the Identity Assumption is false. It is false that Louise-at- $t_{1}$ is identical with Louise-at- $t_{2}$. I know of

12 For more discussion of this response, see William Lane Craig $(1998,125)$. 
two ways in the literature on temporary intrinsics of making this move. The first is the temporal parts solution, put forward by David Lewis $(2001,204)$; the second is the Aristotelian Endurantism solution put forward by Jeffrey Brower (2011). ${ }^{13}$

Lewis claims that persisting objects are composed of temporal parts, each of which bears properties in a non-derivative way. The whole composed of those parts can be said to bear the properties born by its parts in a derivative way, in the same way a road can be bumpy even if only a part of it is bumpy, or a man can be bleeding even if only his hand is bleeding. On Lewis' view, since Louise-at- $t_{1}$ names a temporal part, and Louise-at- $\mathrm{t}_{2}$ names a temporal part, and these temporal parts are different, the Identity Assumption is false, and with it, the third premise.

Brower claims that persisting objects are substances, which enter into larger wholes, composed of substances plus properties. Brower writes of his solution, which he calls the constituent solution:

According to the constituent solution, ordinary objects persist through intrinsic change by successively entering into larger wholes of which they and their temporary intrinsics are proper parts or constituents. Moreover, it is only these larger wholes which have the relevant properties simpliciter, whereas ordinary objects come to have these same properties only by entering into such wholes as parts. Thus, in the particular case of Socrates, an enduring object (namely, Socrates himself) derivatively possesses the properties of bentness and straightness at different times solely by successively being part of two distinct objects (namely, Socrates at $t 1$ and Socrates at $t 2$, respectively), which possess these properties in the primary or proper sense.

On Brower's view, Louise-at- $\mathrm{t}_{1}$ names something - an "accidental unity" of substance and properties - and Louise-at- $t_{2}$ names something distinct - an accidental unity of the same substance but with (at least some) different properties. And so, again, the third premise, which states that Louise-at- $t_{1}$ is identical with Louise-at- $t_{2}$, is false.

This response, then, understands the temporal modification as a modification of the subject (S), it denies the truth of the Identity Assumption, and two common

\footnotetext{
${ }^{13}$ Brower does not view his theory as of a type with Lewis'. He categorizes Lewis' theory as a relativizing solution, whereas his own is, on his categorization, a constituent solution. My own categorization is based on which way the theory understands the temporal modification, and which premise the theory rejects. Both Lewis and Brower understand the temporal modifier to modify the subject, and both consequently reject the Identity Assumption.
} 
examples of this response are the temporal parts response and the Aristotelian

Endurantism response.

\section{Modification of the Predicate (P)}

One might take the temporal modifiers to modify the predicate of the predication.

In such a case, they function in a way similar to the modifiers in the following examples:

"the apple is red-skinned"; "the man is bloody-handed." In such predications, the

predicate itself is modified (signaling a corresponding modification in our

understanding of the properties in question). While the fire hydrant and the apple can

both be red, they cannot both bear the property of being red-skinned. The proponent of this view claims that properties - or at least intrinsic properties - are relativized to the time, just as the predicate "red" in the earlier case is relativized to the skin in "redskinned."

If we understand the temporal modifier to modify the predicate, then some of the premises of the problem should be revised to make this understanding explicit. For instance, $1 \mathrm{t}$ through $5 \mathrm{t}$ should read:

$1 \mathrm{t}(\mathrm{P})$. Louise is straight-at- $\mathrm{t}_{1}$. (Assume.)

$2 t(P)$. Louise is bent-at- $t_{2}$. (Assume.)

$3 t(P)$. Louise is identical with Louise.

(From IdA.)

$4 t(P)$. Straight-at- $t_{1}$ and bent-at- $t_{2}$ are

(From InA.)

$5 t(P)$. Nothing can be both bent-at- $t_{2}$ and straight-at- $t_{1}$.

(From NIP and $4 \mathrm{t}(\mathrm{P})$.)

Understood in this way, these premises offer a way of responding to the problem of temporary intrinsics. For, understood in this way, there is no motivation for affirming the truth of premises $4 \mathrm{t}$ and $5 \mathrm{t}$. While being bent and being straight surely appear incompatible, there is no reason to think that being bent-at- $t_{2}$ and being straight-at- $t_{1}$ are likewise incompatible.

There are two ways one might understand the property time indexing. ${ }^{14}$ It might be that there is a one-place property, straight-at- $t_{1}$, and another, straight-at- $t_{2}$, and another, straight-at- $t_{3}$, etc., and that these properties are had by things in "flickers" - as quickly as times flick by, so quickly do all the intrinsic properties we have flick by.

A second way of understanding these modified properties is to understand them as disguised relational properties. The property is more perspicuously presented as the relation, "straight $t_{x, y}$, where " $x$ " is the entity that is straight, and " $y$ " is the time at which

${ }^{14}$ Lawrence Lombard $(2003,168)$ draws this distinction as well. 
it is straight. ${ }^{15}$ If Louise is straight at both $t_{0}$ and $t_{1}$ before becoming bent at $t_{2}$, then she has the same property at those two times $\left(t_{0}\right.$ and $\left.t_{1}\right)$, but she has it with respect to different times. 16

In either case, whether we understand the properties as one-place or two-place, the motivation for accepting The Incompatibility Assumption is vitiated. There is no reason for thinking that Louise's being straight-at- $t_{1}$ is inconsistent with her being bentat- $t_{2}$, and there is no reason for thinking that straight $t_{\text {Louise }, t 1}$ is inconsistent with bent $t_{\text {Louise,t2 }}$ or even inconsistent with $\sim$ straight $t_{\text {Louise,t2. }}$

This response, then, understands the temporal modification as a modification of the predicate $(\mathrm{P})$, it denies the truth of the Incompatibility Assumption, and two examples of this response stem from the one-place and two-place understandings of the intrinsic properties. ${ }^{17}$

\section{Modification of the Copula (C)}

One might take the temporal modifiers to modify the copula of the predication.

In such a case, they function in a way similar to the modifiers in the following example from Lowe $(1988,75)$ : “The Thames is broad in London." On this view, it is the river, not some segment of it, that is the subject of the predication. And what is being predicated is not some property, London-ized broadness. It is the characterizing of the Thames as broad that is being modified. As Lowe writes $(1988,75)$, we should understand the predication as:

'The Thames is-in-London broad' (modifying the ascription of broad-ness to the Thames by an adverb of place which specifies where along its length the Thames is broad).

The proponent of this view claims that the copula - at least in predications of intrinsic properties - is relativized to the time.

\footnotetext{
15 The common objection to such a move is that it makes the intrinsic property into a disguised relational property.

16 This is not to claim that she is no longer straight-at- $t_{0}$ at $t_{1}$, but to claim that the same property is had by her in relation to two different things, just like Minneapolis might be aptly predicated by "north of" in relation to both Chicago and South Bend.

17 This solution is defended by Ryan Wasserman (2003); D.H. Mellor (1985) defended a relational theory of properties. But he later revised his view (1998, xii), saying that in his earlier project he "argued that any changeable property $F$ (e.g., a temperature) of a thing $a$ is a relation $a$ has to any B-moment [a moment in the B-series] $t$ when it is $F$. I am now persuaded that this is wrong." His revised view, it seems to me, is a response of the (A) variety.
} 
This is what Sally Haslanger calls the second way of incorporating temporal elements into semantics. She writes $(1989,121)$ that

the second is to include temporal elements in the proposition without incorporating them into the semantical value of the predicate (or the subject)... $[T]$ reating time as an additional constituent of the proposition (perhaps not explicit in the sentence expressing the proposition but determined via the context of utterance) offers eternalist propositions.

If we understand the temporal modifier to modify the copula, then some of the premises of the problem should be revised to make this understanding explicit. For instance, $1 \mathrm{t}$ through 3 t should read:

$1 \mathrm{t}(\mathrm{C})$. Louise is-at- $\mathrm{t}_{1}$ straight.

$2 t(C)$. Louise is-at- $t_{2}$ bent.

$3 t(C)$. Louise is identical with Louise. ${ }^{18}$
(Assume.)

(Assume.)

(From IdA.)

Understood in this way, these premises offer a way of responding to the problem of temporary intrinsics. For, understood in this way, there is no motivation for affirming the truth of premise $5 \mathrm{t}$. Being bent and being straight are incompatible, when the same copula is used in the same relativized way in both cases, but there is no reason to think that bent and straight are likewise incompatible when Louise is-at- $\mathrm{t}_{2}$ bent and she is-at- $\mathrm{t}_{1}$ straight.

Again, just as in the $(\mathrm{P})$ response, there are two ways one might understand the copula time indexing. ${ }^{19}$ The first way is to posit distinct copulas for each time; there is the copula is-at- $\mathrm{t}_{1}$, the copula is-at- $\mathrm{t}_{2}$, etc. As quickly as times flick by, so quickly do all the properties that we have intrinsically become had by us by means of a different copula. You have the same property across times, unlike the $(\mathrm{P})$ view, but you have it in different ways, in virtue of different copulas, across time.

A second way of understanding the modified copula is to understand it as having a hidden variable. One can substitute in different times into the variable, just as one can substitute in different objects into the places of standard predicates.

In either case, whether we understand the copulas as one-place or two-place, the motivation for accepting No Incompatible Properties is vitiated. The proponent of this

\footnotetext{
18 This is the "is" of identity, which the copula theorist could, but need not, relativize. If she were to modify it, she might say at $3 t(C)$ that, for any $t_{n}$, Louise is-at- $t_{n}$ identical to Louise.

${ }^{19}$ Bradley Rettler $(2012,432)$ draws this distinction as well.
} 
response might put it like this: I distinguish No Incompatible Properties. First, I concede that nothing can have incompatible properties when indexing the copula in the same way in both cases. But I deny that the copula is so indexed in the same way in both premises $1 \mathrm{t}$ and $2 \mathrm{t}$. Second, I deny that nothing can have incompatible properties when indexing the copula in different ways in both cases. And I claim that this case, the case of $1 \mathrm{t}$ and $2 t$, is such a case.

This response, then, understands the temporal modification as a modification of the copula (C), it distinguishes No Incompatible Properties into a true but harmless reading and a harmful but false reading, and two examples of this response stem from whether or not the copula is the same in each case or not. ${ }^{20}$

\section{Summary of Responses}

I see three ways of dividing up the information about the responses: by which way it understands the temporal modification, by which premise or assumption it denies, and by which extant solutions it maps on to. I will represent that information below in a table. Let a theory of copula or predicate relativizing be "non-substitutional" when it does not allow any substitution of temporal modifiers into the predicate or copula. The first of the two relativizing views discussed in both the $(\mathrm{P})$ and $(\mathrm{C})$ sections was a non-substitutional view. Let a copula or property be "substitutional" when it does allow the temporal modifiers to be substituted in. The second of the two relativizing views discussed in both sections was a substitutional view. With this terminology in mind, the table looks like this:

\begin{tabular}{|l|l|l|}
\hline How "at $\mathbf{t}_{\mathbf{n}}$ " works: & $\begin{array}{l}\text { By the Premise or inference it } \\
\text { Denies: }\end{array}$ & By the Extant Solutions: \\
\hline $\begin{array}{l}\text { It signals the tense of the } \\
\text { predication }(\mathrm{T})\end{array}$ & $\begin{array}{l}\text { Revise at least one predication } \\
\text { and } 7 \mathrm{t} \text {; deny inference to } 8 \mathrm{t}\end{array}$ & Serious Tensing / Presentism \\
\hline $\begin{array}{l}\text { It modifies the assertion } \\
(\mathrm{A}): \text { "at } \mathrm{t}, \mathrm{x} \text { is F" }\end{array}$ & $\begin{array}{l}\text { Revise both predications; deny } \\
\text { inference to 6t(A) }\end{array}$ & $\begin{array}{l}\text { Haslanger's first adverbial } \\
\text { account }\end{array}$ \\
\hline $\begin{array}{l}\text { It modifies the subject (S): } \\
\text { " } \mathrm{x} \text {-at-t is F" }\end{array}$ & $\begin{array}{l}\text { Deny the Identity Assumption; } \\
\text { deny premise 3t }\end{array}$ & $\begin{array}{l}\text { Temporal Parts / } \\
\text { Aristotelian Endurantism }\end{array}$ \\
\hline $\begin{array}{l}\text { It modifies the predicate } \\
(\mathrm{P}): \text { " } \mathrm{x} \text { is F-at- } \mathrm{t} \text { " }\end{array}$ & $\begin{array}{l}\text { Deny the Incompatibility } \\
\text { Assumption; deny premises 4t \& } \\
5 \mathrm{t}\end{array}$ & $\begin{array}{l}\text { Substitutional Relativizing / } \\
\text { Non-substitutional Relativizing }\end{array}$ \\
\hline
\end{tabular}

${ }^{20}$ For more on this response to the problem of temporary intrinsics, see Ben Caplan (2005), M. Oreste Fiocco (2010, 72-74) Sally Haslanger (1989), David Lewis (2001; 1988; 2002), E.J. Lowe (1987; 1988; Lowe 2002, 47-49). Lowe $(1988,73)$ "plump[s] for" this solution. 


\begin{tabular}{|l|l|l|}
\hline $\begin{array}{l}\text { It modifies the copula (C): } \\
\text { "x is-at-t F" }\end{array}$ & $\begin{array}{l}\text { Deny No Incompatible } \\
\text { Properties; deny premise 5t }\end{array}$ & $\begin{array}{l}\text { Substitutional Relativizing / } \\
\text { Non-substitutional Relativizing }\end{array}$ \\
\hline
\end{tabular}

This concludes my discussion of the solutions to the problem of temporary intrinsics. In the next section I discuss the problem of natural intrinsics, then in the following section I discuss answers to that problem analogous to the responses presented in this section.

\section{THE PROBLEM OF NATURAL INTRINSICS}

Traditional Christology teaches that there is one person, the Second Person of the Holy Trinity, who assumed a human nature, and so became a true man, and was crucified. For the purposes of this paper, I will assume Traditional Christology to be what one might call Conciliar Christology, the Christology taught in the conciliar statements of the first seven Ecumenical Councils: The First Council of Nicaea, 325; The First Council of Constantinople, 381; The Council of Ephesus, 431; The Council of Chalcedon, 451; The Second Council of Constantinople, 553; The Third Council of Constantinople, 680-681; The Second Council of Nicaea, 787. These councils are viewed as authoritative by both Catholic and Orthodox Christians. ${ }^{21}$ Furthermore, very many Protestant Christians consider some subset of these councils as binding, in some sense. Moreover, very few Christians would be willing to part ways with the Christology taught at the Council of Chalcedon, which proclaimed Jesus Christ to be the very same person as the Second Person of the Trinity, and to have two complete and unmixed natures, one divine, and the other human.

The Church fathers at the Third Council of Constantinople, in their Exposition of the faith, summarize most of the important claims of Conciliar Christology in the following passage:

Following the five holy and universal synods and the holy and accepted fathers, and defining in unison, it [the Third Council of Constantinople] professes our lord Jesus Christ our true God, one of the holy Trinity, which is of one same

\footnotetext{
${ }^{21}$ Catholic Christians view these seven councils as the earliest, but not the only ecumenical councils, while many Orthodox Christians would consider these, not just the earliest, but the only ecumenical councils. In the following, unless otherwise noted, any quotation from an Ecumenical Council is taken from Norman Tanner's (1990) excellent 2 volume edition, Decrees of the Ecumenical Councils. By "conciliar statements," I mean the definitions and expositions of faith, creeds, canons, and anathemas of the councils. If such definitions accept other documents (e.g., as Chalcedon's Definition of the Faith accepts both Cyril's letters to Nestorius and to John of Antioch, as well as Leo's Tome), I will include those other documents as part of what I take to be "conciliar statements."
} 
being and is the source of life, to be perfect in divinity and perfect in humanity, the same truly God and truly man, of a rational soul and a body; consubstantial with the Father as regards his divinity, and the same consubstantial with us as regards his humanity; like us in all respects except for sin; begotten before the ages from the Father as regards his divinity, and in the last days the same for us and for our salvation from the holy Spirit and the virgin Mary, who is properly and truly called mother of God, as regards his humanity; one and the same Christ, Son, Lord, onlybegotten, acknowledged in two natures which undergo no confusion, no change, no separation, no division; at no point was the difference between the natures taken away through the union, but rather the property of both natures is preserved and comes together into a single subsistent being (Tanner 1990, 127-128).

The one person - "one and the same Christ, Son, Lord, only-begotten" - has the proper characteristics that anything would have, were it to have either of the natures that Christ has. No characteristic is lost or diminished in the incarnation. And so Cross rightly asks

How is it that one and the same thing could be both divine (and thus, on the face of it, necessary, and necessarily omniscient, omnipotent, eternal, immutable, impassible, and impeccable) and human (and thus, on the face of it, have the complements of all these properties)?

Does Conciliar Christology really make such apparently contradictory claims of Christ?

We find the collected church fathers at the councils making such claims of Christ. The collected fathers at the Council of Ephesus believed so firmly in the immutability and impassibility of the divine nature of Christ that they endorse Cyril's claim:

I think that those are quite mad who suppose that "a shadow of change" is conceivable in connexion [sic] with the divine nature of the Word. For he remains what he is always and never changes, nor could he ever change or be susceptible of it. Furthermore, we all confess that the Word of God is impassible, though in his all-wise economy of the mystery he is seen to attribute to himself the sufferings undergone by his own flesh (Tanner 1990, 7273).

Yet the same fathers are adamant in their acceptance of the Nicene Symbol, which includes the claim that the same Christ, Son, and Lord "suffered and rose up," which requires changeability and passibility of the Word of God (Tanner 1990, 5). How is this 
anything more than an obvious and odious contradiction? And if this was not enough of an obvious and odious contradiction, the fathers at Second Nicaea provide a cornucopia of (alleged) contradiction in a quintuply inconsistent assertion.

The Fourth Council of Constantinople (869-870 AD), which is the $8^{\text {th }}$ Ecumenical Council (on the Catholic reckoning of things, and so not itself part of Conciliar Christology, as I have defined the term), says the following about the $7^{\text {th }}$ Ecumenical Council, Second Nicaea (which is a part of Conciliar Christology, as I have defined the term):

We also know that the seventh, holy and universal synod, held for the second time at Nicaea, taught correctly when it professed the one and same Christ as both invisible and visible (invisibilem et visibilem) lord, incomprehensible and comprehensible (incomprehensibilem et comprehensibilem), unlimited and limited (incircumscriptum et circumscriptum), incapable and capable of suffering (impassibilem et passibilem), inexpressible and expressible (inscriptibilem et scriptibilem) in writing (Tanner 1990, 162).

If this passage is correct about Second Nicaea, then Traditional Christology entails the truth of both "Christ is passible" and "Christ is impassible"; of "Christ is visible" and "Christ is invisible," and so on. And it is one and the same Christ who has these seemingly incompatible properties. But how can this be?

One can formulate the argument here in the same way I formulated the problem of temporary intrinsics above. I will use as an example pair of incompatible properties (or merely allegedly incompatible, on some responses to the problem) passible and impassible, which we have seen the councils attribute to the person of Christ multiple times. ${ }^{22}$

1n. Christ qua divine is impassible.

(Assume.)

$2 n$. Christ qua human is passible.

(Assume.)

$3 \mathrm{n}$. Christ qua human is identical with Christ qua divine.

(From IdA.)

4n. Passible and impassible are incompatible intrinsic properties.(From InA.)

$5 \mathrm{n}$. Nothing can be both passible and impassible.

(From NIP and 4n.)

6n. Christ qua divine is passible.

$7 \mathrm{n}$. Christ qua divine is both passible and impassible.

(From 2n, 3n, and II.)

8 n. Contradiction!

(From $1 \mathrm{n}$ and $6 \mathrm{n}$.)

(From 5n and 7n.)

${ }^{22}$ For another example, see the Third Letter of Cyril to Nestorius, accepted by Chalcedon's Definition of the Faith (Tanner 1990, 85), which claims "We also confess that the only begotten Son born of God the Father, although according to his own nature he was not subject to suffering, suffered in the flesh for us according to the scriptures" (53). 
Again, the four assumptions, along with the two predications at $1 \mathrm{n}$ and $2 \mathrm{n}$, yield a contradiction.

Premise 3n might cause worry. Isn't it false? The answer to that question depends on what the "qua" clause is doing. If "Christ qua human" and "Christ qua divine" are terms that refer to persons, then the identity claim is true. The person referred to with one phrase is identical to the person referred to with the other phrase, according to Conciliar Christology. One might be inclined to think that the phrases "Christ qua human" and "Christ qua divine" name two different parts or aspects of the one person, Christ. In that case, the third premise is false, as it is for the two (S) approaches discussed above (for the problem of temporary intrinsics) and below (for the problem of natural intrinsics). On the $(\mathrm{P})$ and $(\mathrm{C})$ readings, the modifier is moved elsewhere, so the phrase "Christ qua human" is expunged from the third premise, as we will see later. Rather, the third premise makes the hardly objectionable claim that Christ is identical with Christ.

In the following section I discuss the responses analogous to those presented in section III, which one might give to the problem of natural intrinsics.

\section{ANALOGOUS SOLUTIONS TO THE PROBLEM OF NATURAL INTRINSICS}

One common initial reaction to this problem is to claim that while it is true that both properties, passible and impassible, are had by the same one person, they are not had by that person according to the same nature. The response often continues by pointing out some of the numerous places where Conciliar statements or time-honored theologians have made this very move. For instance, the long quotation from Third Constantinople makes this sort of move no fewer than four times. ${ }^{23}$ Nowadays, the notion is rendered by the word "qua." It is qua his human nature that Christ is consubstantial with humans, and that he ate or wept. It is qua his divine nature that Christ is consubstantial with the Father and begotten before all ages.

This initial reaction is on the right track, but it is insufficient, on its own, to answer the argument presented above. What we need is some way of denying some premise or inference of the problem of natural intrinsics, and this initial reaction, by itself, provides no means.

${ }^{23}$ The phrase "as regards" in both instances each of "as regards his divinity" and "as regards his

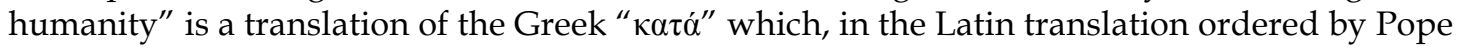
Leo II is rendered "secundum." 
One helpful way to work through different ways of understanding this initial reaction is to consider different ways that the modifier "qua $N$," where " $\mathrm{N}$ " names a nature, might modify the premises of the argument. By my lights, the same six ways apply here as did above. Letting the name " $\mathrm{C}$ " refer to Christ, the predicates " $\mathrm{P}$ " and "I" stand for "passible" and "impassible," respectively, and " $\mathrm{D}$ " and " $\mathrm{H}$ " stand for the divine and human natures, respectively, we can represent the four ways as follows, hyphenating the natural modifier into the relevant parts of the predication in the last three options: 24

$\begin{array}{lll}\text { Assertion (A): } & \text { Qua H, C is P } & \text { Qua D, C is I } \\ \text { Subject (S): } & C \text {-qua-H is P } & \text { C-qua-D is I } \\ \text { Predicate (P): } & \text { C is } P \text {-qua-H } & \text { C is I-qua-D } \\ \text { Copula (C): } & \text { C is-qua-H P } & \text { C is-qua-D I.25 }\end{array}$

Likewise, some unstated part of the predication might be made explicit and modified by the "qua," as the final solution in this section might well say. Finally, one might view the "qua," not as appending something to the proposition or one of its parts, but rather as signaling how to understand some part or parts of the proposition. Below I consider replies to the problem of natural intrinsics analogous to the responses to the problem of temporary intrinsics.

\section{Taking Tense Seriously ( $T$ )}

One response to the problem of natural intrinsics collapses the problem back into the problem of temporary intrinsics. According to Kenotic Christology, when the Word became incarnate, he emptied himself of some properties that he previously had. ${ }^{26}$ The

\footnotetext{
${ }^{24}$ I find it interesting as a further analogy between these problems that, much like Lowe hyphenates solutions to the problem of temporary intrinsics, Thomas Senor (2002), independently, so far as I can tell, hyphenates solutions to the problem of natural intrinsics. ${ }^{25}$ Why not abbreviate "impassible" as " $\sim \mathrm{P}$ "? The answer is that later I will consider a response that denies that the predicate, "impassible," when used by the church fathers, was meant to be incompatible with "passible." Given that possible response, symbolizing the two predicates as " $\mathrm{P}$ " and " $\sim \mathrm{P}^{\prime}$ would be most confusing in that discussion.

${ }^{26}$ A history of Kenotic Christology is given in brief by Stephen Davis (2011, 114-115), C. Stephen Evans $(2006,3-5)$ and Thomas Senor $(2011,102-103)$ and in much greater depth by Thomas Thompson (2006). For expositions of Kenotic Christology, see Davis (2011), Evans (2006), Forrest (2009) and Senor (2011).
} 
Word was, say, omnipotent and omniscient, but as incarnate in a human, he gave up these attributes to become more like us in power and knowledge. ${ }^{27}$

Such responses do not often make use of "qua" clauses, but if the Kenotic theorist were to explain the "qua" clauses used in the Conciliar texts, she might do so by saying that the conciliar fathers were attempting to point to that in virtue of which the predications are true when they are, in fact, true. But I think a more common response to "qua" clauses from Kenotic thinkers is to strike them from their theory. ${ }^{28}$

If we assume a Kenotic Christology, then some of the premises of the problem should be revised to make this understanding explicit. First, the "qua" clauses will be struck. Second, temporal modifiers will be inserted to mark when the problematic properties are had by the Word and when they are not. Suppose, again, that $t_{2}$ is the present time, and also that we are considering the argument during Christ's earthly ministry. Let $t_{1}$ be a pre-incarnational time. The name "Christ" is not often used for the Word when not incarnate. As such, in what follows, I will use the name "the Word" in the revised premises. In such a case, we might revise premises $1 \mathrm{n}$ and $2 \mathrm{n}$ as follows:

$1 \mathrm{n}(\mathrm{T})$. The Word was impassible.

$2 \mathrm{n}(\mathrm{T})$. The Word is passible. ${ }^{29}$

3n(T) might be stated:

$3 \mathrm{n}(\mathrm{T})$. There is one person, the Word, and he existed at $\mathrm{t}_{1}$ and exists at $\mathrm{t}_{2}$.
(Assume.)

(Assume.)

Premises $4 \mathrm{n}$ and $5 \mathrm{n}$ remain the same and go unquestioned according to this response.

Premises 6n would be revised as follows:

$6 n(T)$. The Word at $t_{1}$ is passible.

(From 2n, 3n, and II.)

As previously, this will be granted by the serious tenser, on the assumption that the definite description "The Word at $t_{1}$ " names the person of the Word and says of him that

\footnotetext{
${ }^{27}$ For discussion of what the "giving up" amounts to, see Davis (1983, chap. 8; 1988, 52; 2006, 118; 2011, 121).

${ }^{28}$ For a notable exception, see the work of Davis $(1988,56)$, who, though a kenotic theorist, makes use of "qua" clauses to answer the problem of natural intrinsics.

${ }^{29}$ The majority of Kenotic theorists deny impassibility as a divine attribute. But there are other attributes which they claim that the Word had prior to the incarnation and gave up when incarnated. Those Kenotic theorists uncomfortable with impassibility are free to substitute in some other property sloughed off at the incarnation. If no property was so given up, then it is hard to see how the thinker qualifies as a Kenotic thinker.
} 
he existed at $t_{1}$ : the person identical with that person (the person existing now at $t_{2}$, who did exist at $\mathrm{t}_{1}$ ) is passible.

The problem for the problem, according to the proponents of Kenotic Christology, is that $7 \mathrm{n}$ does not follow from $1 \mathrm{n}$ and $6 \mathrm{n}$, properly understood. For $7 \mathrm{n}$ does not take into account the irreducible tense of the conjuncts which it conjoins. $7 \mathrm{n}$ ought to read, according to the Kenotic Christologist:

$7 \mathrm{n}(\mathrm{T})$. The Word at $\mathrm{t}_{1}$ is passible and was impassible.

(From $1 \mathrm{n}(\mathrm{T})$ and $6 \mathrm{n}(\mathrm{T})$.

That claim, though, entails no contradiction when conjoined with $5 \mathrm{n}$ - nothing, not even the God-man, is both passible and impassible, on this Kenotic view. And so no contradiction is derived at step $8 \mathrm{n}$.

This response, then, claims that at least one of the initial predications ( $1 n$ or $2 n$ ) is false, and that, when it is revised so as to make it true, $7 \mathrm{n}$ does not follow. Rather, $7 \mathrm{n}(\mathrm{T})$ follows, which does not yield a contradiction when conjoined with $5 \mathrm{n}$, contra $8 \mathrm{n}$. A common example of this sort of response is Kenotic Christology.

\section{Modification of the Whole Assertion (A)}

One might take the nature modifiers to modify the entire predication. In such a case, they function in a way similar to the modifiers in the following example: "He has an office qua adjunct instructor in the Department, not qua spouse of a faculty member."

If we understand the modifier to modify the whole assertion, then some of the premises of the problem should be revised to make this understanding explicit.

Premises 1n, 2n, 3n, 6n, 7n should all have the modifier moved to the very beginning of the sentence. For instance, $1 \mathrm{n}$ and $2 \mathrm{n}$ should read:

$1 \mathrm{n}(\mathrm{A})$. Qua divine, "Christ is impassible" is true. (Assume.)

$2 n(A)$. Qua human, "Christ is passible" is true. (Assume.)

In the problem of temporary intrinsics, at this point we had a means to deny one or the other of these starting premises. The prognosis is less optimistic here.

Haslanger's response worked by claiming that predications can change truthvalues, that propositions are to be evaluated at times, and that statements such as "At $t_{1}$, 'Louise is straight' is true" are defined in terms of the proposition, Louise is straight, standing in a certain relation to $t_{1}$. She writes $(1989,122)$ :

The three-place relation indicated above, viz., the relation between an object $a$, property $F$, and time $t$, such that the proposition that $a$ is $F$ holds at $t$, is a relation defined partly 
in terms of a more basic notion of $a$ 's being $F$, i.e., of an object instantiating its properties.

If we understand predications such as $1 \mathrm{n}(\mathrm{A})$ in a similar way, we should say that the premise, "qua divine, 'Christ is impassible' is true," is defined in terms of the proposition Christ is impassible standing in a certain relation to the divine nature.

It seems to me that this is precisely the "qua" move that has garnered the most explicit criticism in the Christological literature. Thomas Morris writes $(1987,48-49)$, in an oft-quoted passage about the problems with "qua" clauses:

Consider any conjunctive reduplicative proposition of the form ' $x$ as $A$ is $N$ and $x$ as $B$ is not $N$.' If the subjects of both conjuncts are the same and the substituends of $N$ are univocal across the conjunction, then as long as (1) the reduplication predicates being $A$ of $x$ and predicates being $B$ of $x$, and (2) being $N$ is entailed by being $A$, and not being $N$ is entailed by being $B$, then the reduplicative form of predication accomplishes nothing except for muddying the waters, since in the end the contradiction stands of $x$ being characterized as both $N$ and not $N .{ }^{30}$

It seems to me, too, that this response just muddies the waters. If this is the intended understanding of "qua," then it will not solve the problem. ${ }^{31}$ For on this interpretation of the modifier, both unmodified predications come out as true at the same time (nothing about evaluating propositions according to natures makes them untrue at the same time). That is, if "qua human, 'Christ is passible" is true, and the "qua" clause merely points to that in virtue of which the appended predication ought to be evaluated, and Christ is human throughout the entirety of his earthly ministry, then the predication, "Christ is passible," is true during that ministry. But likewise for the predication "qua divine, 'Christ is impassible,'" since he is divine at those same times. But then we have done nothing to thwart the contradiction arrived at in 8n. And so, on this interpretation of the "qua" clause, the problem of natural intrinsics is not solved.

\section{Modification of the Subject (S)}

Consider the second way to understand "qua"-clauses - the "qua" modifies the subject. In the $(S)$ method, we understand the "qua human" modifier as modifying the

\footnotetext{
30 Peter van Inwagen (1998, sec. 4) asks a similar question.

31 This is a common claim in the literature. See, for instance, Adams (2009, 254-255), Bäck (1998, 84-87), Cross (2005, 193-195; 2011, 455-456), Morris (1987, 48-49), and Senor (2002, 229).
} 
subject of the predication. When we say "Christ is passible qua human" we are really saying that there is a subject, Christ-qua-human, and that subject bears the property of being passible.

Making the representation explicit, the first three premises would appear like so:

$1 \mathrm{n}(\mathrm{S})$. Christ-qua-divine is impassible.

(Assume.)

2n(S). Christ-qua-human is passible.

(Assume.)

$3 \mathrm{n}(\mathrm{S})$. Christ-qua-divine is identical with Christ-qua-human. (From IdA.)

If we were to follow the route of the (S) solutions to the problem of temporary intrinsics, we would claim that the culprit is the Identity Assumption. I presented two (S) responses to the problem of temporary intrinsics.

Consider the temporal parts solution. We might analogize it to the natural problem as follows. Louise, the whole person, composed of all those temporal parts, is straight derivatively, in virtue of her $\mathrm{t}_{1}$ part being straight non-derivatively. Likewise, Christ, the whole person, composed of both those natural parts, is passible derivatively, in virtue of his human part being passible non-derivatively. ${ }^{32}$

Consider the Aristotelian Endurantist solution. We might analogize it to the natural problem as follows. Louise, the substance part of larger hylomorphic compounds, which enters sequentially into larger wholes that are composed of the substance along with properties, is straight derivatively in virtue of the whole she is part of at $t_{1}$ being straight non-derivatively. Likewise, the Second Person of the Trinity enters into a whole, composed of the two natures, along with the properties had by those natures (or, if the divine nature has no properties, then the properties of the human nature alone). The Second Person of the Trinity, on this view, is derivatively passible because he is part of an accidental unity that is passible simpliciter. 33

32 The language of composition here might worry some traditional theologians. Thomas Flint $(2012,190)$ writes: "if CHN was assumed by the Son of God, then CHN was a part (or, more plausibly, something rather like a part) of an essentially impeccable person." And Joseph Pohle $(1913,145)$ writes that the ecumenical councils, the church fathers, and the medieval schoolmen all write of hypostasis Christi composita, that is, of the composite hypostasis of Christ. Though he hastens to add (Pohle 1913, 146) that this composition "cannot be conceived strictly as a component part (compars) or ingredient of the Logos, or of the totum which it forms together with the Logos. For this reason theologians usually designate the sacred humanity of our Redeemer as quasi-pars or conceive it per modum partis, i.e., as a component part in a purely figurative sense." ${ }^{33}$ One wonders here: If the divine nature retains whatever it is in virtue of which Christ is impassible, since that item is part of the larger composite accidental unity which also includes a part in virtue of which Christ is passible, wouldn't this make that accidental unity as a whole both non-derivatively impassible as well as non-derivatively passible? 
Interestingly, these two views map nicely onto two mereological views of composition available in the literature on Christology. Thomas Flint (2011) calls these two views Model A and Model T, respectively, claiming that Model A was held by St. Thomas Aquinas, and that Model T was held by Duns Scotus and, in the contemporary debate, by Brian Leftow (2004).

Flint $(2011,71)$ describes Model A as analogous with “a case of a substance's gaining a part":

The Son, one might think, exists prior to becoming incarnate as a simple divine being. In becoming human, the Son or Word of God takes on [Christ's Human Nature, "CHN," a composite of a human body and soul] as a part. This assumption results in a Son who combines both his original divine substance and his created human nature.

Model A is analogous to the picture one gets of a temporal parts view when combined with a growing block theory of time, in which a substance gains new temporal parts as the new slices of the $4 \mathrm{D}$ block accumulate.

Flint $(2011,79)$ describes Model T as follows:

[T] he Son unites himself to CHN in the incarnation. But the composite thus formed is not the Son. The Son remains simply one part of the composite entity that results from his assuming a human nature. That composite entity, which we can call Christ, is a contingent thing, composed of another contingent entity $(\mathrm{CHN})$ and of a necessary one (the Son). ${ }^{34}$

Model T is analogous to Brower's Aristotelian Endurantism view wherein the person (Socrates himself, in Brower's example) is not the whole accidental unity but a part of the composite whole that comes about, and the person is characterized derivatively by the properties the whole has simpliciter.

As with the previous cases, these views have been both defended and criticized in the Christological literature. So, for instance, Brian Leftow $(2004 ; 2011)$ and Eleonore Stump (2004; 2005, chap. 14) have defended some form of the (S) view. Marilyn McCord Adams (2009, 255-256), Richard Cross (2005, 195-199; 2011, 456), and a duo of Doubting Didymoi, the Thomases Senor (2007) and Flint (2011), have criticized the theological and philosophical viability of such a Christology.

${ }^{34}$ In both of the quotations from Flint I have dropped parenthetical remarks, primarily namings, e.g., "(whom I'll label W)," and references, that are unnecessary for my purposes here. 
This response, then, understands the modification as a modification of the subject (S), it denies the truth of the Identity Assumption, and two examples of this response are Models A and T.

\section{Modification of the Predicate (P)}

Consider the third way to read the "qua"-clauses - the way of modifying the predicate. The property that Christ bears, on this view, is not passible simpliciter. Rather, properties should be understood as internally modified. The property that Christ has is really passible-qua-human. If we understand the modifier as modifying the property (or, as modifying the predicate, which modification is intended to signal a certain way of understanding the property; namely, as modified in the sense spelled out above), then some of the premises of the problem should be revised to make this understanding explicit. For instance, $1 \mathrm{n}$ through $5 \mathrm{n}$ should read:
$\ln (\mathrm{P}) . \quad$ Christ is impassible-qua-divine.
(Assume.)
$2 \mathrm{n}(\mathrm{P})$. Christ is passible-qua-human.
(Assume.)
$3 n(P)$. Christ is identical with Christ.
(From IdA.)
$4 \mathrm{n}(\mathrm{P})$. Passible-qua-human and impassible-qua-divine are incompatible intrinsic properties.
(From InA.)
$5 \mathrm{n}(\mathrm{P})$. Nothing can be both passible-qua-human and impassible-qua-divine
(From NIP and $4 \mathrm{n}(\mathrm{P})$.

Understood in this way, these premises offer a way of responding to the problem of natural intrinsics. For, understood in this way, there is no motivation for affirming the truth of premises $4 \mathrm{n}$ and $5 \mathrm{n}$. While being passible (full stop) and being impassible (full stop) surely appear incompatible, there is no reason to think that being passible-quahuman and impassible-qua-divine are likewise incompatible.

We can understand this internal modification in two ways, non-substitutionally and substitutionally, as I explained in the corresponding section on the problem of temporal intrinsics. We might take passible really to mean passible-qua-human (or passible-qua-mammal, or passible-qua-creature, or ... ), where there is no variable within the property, or we might take it to mean passible-qua- $\mathrm{N}$, where " $\mathrm{N}$ " is a variable into which different nature types can be substituted. In either case, whether we understand the properties as one-place or two-place, the motivation for accepting The Incompatibility Assumption is vitiated.

We find this sort of response in the Christological discussion. Marilyn McCord Adams (2009, 253-260) defends it, and Alan Bäck $(1998,93)$ claims this to be the view of 
Scotus. (It appears Scotus got around in the incarnational debates.) Richard Cross (2005, 204-205; 2011, 457), and Thomas Senor (2002, 230-233), on the other hand, criticize the (P) response.

This response, then, understands the modification as a modification of the predicate $(\mathrm{P})$, it denies the truth of the Incompatibility Assumption, and two examples of this response stem from the one-place and two-place understandings of the intrinsic properties.

\section{Modification of the Copula (C)}

One might take the modifiers to modify the copula of the predication. If we understand the modifier to modify the copula, then some of the premises of the problem should be revised to make this understanding explicit. For instance, 1n through $3 n$ should read:
$\ln (\mathrm{C})$. Christ is-qua-divine impassible.
(Assume.)
$2 \mathrm{n}(\mathrm{C})$. Christ is-qua-human passible.
(Assume.)
$3 n(C)$. Christ is identical with Christ.
(From IdA.)

Understood in this way, these premises offer a way of responding to the problem of natural intrinsics. For, understood in this way, there is no motivation for affirming the truth of premise 5n. Being passible and being impassible are incompatible (this reply can concede), when the same copula is used in the same relativized way in both cases, but there is no reason to think that being-qua-human passible and being-qua-divine impassible are likewise incompatible.

We can understand this internal modification in two ways, non-substitutionally and substitutionally, as I explained in the corresponding section on the problem of temporal intrinsics. In either case, whether we understand the properties as one-place or two-place, the motivation for accepting No Incompatible Properties is vitiated.

The proponent of this response might put it like this: I distinguish No Incompatible Properties. First, I concede that nothing can have incompatible properties when indexing the copula in the same way in both cases. But I deny that the copula is so indexed in the same way in both premises $1 \mathrm{n}$ and $2 \mathrm{n}$. Second, I deny that nothing can have incompatible properties when indexing the copula in different ways in both cases. And I claim that this case, the case of $1 n$ and $2 n$, is such a case. 
I know of no thinker in the Christological debates who employs the copula indexing move. ${ }^{35}$ Peter van Inwagen, an apparent defender of the (C) response to the problem of temporary intrinsics $(1990,248)$, does not put forward a (C) response to the Christological problem. Rather, he offers a response of the final sort I will discuss: that of relativizing identity $(1988 ; 1998) .{ }^{36}$

This response, then, understands the modification as a modification of the copula (C), it denies the truth of No Incompatible Properties, and two examples of this response stem from whether the copula is the same in each case or not.

\section{Relative Identity (R)}

One final response to the problem focuses on an as-of-yet unquestioned assumption of the arguments from temporal and natural intrinsics: the Indiscernibility of Identicals. Denying the Indiscernibility of Identicals undercuts the justification for the inference to 6 n. One way to deny the Indiscernibility of Identicals is to relativize identity claims.

One might think that standard identity claims, such as "Barack is the same as President Obama" are incomplete. They are missing an important index: they must be indexed to a particular sort of thing (a "sortal") in order to be complete. According to the proponent of this view, the complete identity claim must be something like Barack is the same person as or the same human as or the same president as President Obama. On this view, the "qua" clause works to point out a sortal tacitly included in the identity claim.

Peter van Inwagen (1998), the most able defender of this response to the problem of natural intrinsics, puts the opening moves of this response as follows:

Suppose that, although God is not (of course) the same substance or being as the human being Jesus of Nazareth, he is nevertheless the same person - the same ' $\mathrm{I}$ ' or 'thou' or 'he'. (This assumption has two closely related presuppositions: that it is possible for $x$ to be the same

\footnotetext{
${ }^{35}$ For a different sort of adverbial view in the Christological debate, see (Bohn 2012).

${ }^{36}$ An additional benefit that accrues to the proponent of (C) theories is that it provides, as Bradley Rettler (2012) has shown, an answer to McTaggart's argument for the unreality of time as well. William Lane Craig (1998) has argued that McTaggart's paradox is a special case of the problem of temporary intrinsics, and that of the (A), (S), and (P) solutions, only the (A) solution functions to resolve McTaggart's paradox. The (A) solution fails, though, as a response to the problem of natural intrinsics. And so, if Craig and Rettler are correct in their arguments (though see Oaklander (1999) in response to Craig), then the only response I have canvassed that works to solve all three problems - the problems of natural and temporary intrinsics, and McTaggart's Paradox - is the (C) solution.
} 
person as $y$ but not the same substance; and that if $x$ is the same person as $y$, and $x$ has the property $F$, it does not follow that $y$ has $F$.)

While the entire strategy and response is interesting and repays careful study, it is the second of these two presuppositions that is relevant for the problem of natural intrinsics.

According to the relative identity theorist, the argument ought to be stated differently. Let "Christ-qua-human" be a name of the person who is a human, born of Mary, suffered under Pontius Pilate, etc. And let "Christ-qua-divine" be a name of the person who is one with the Father, through whom all things were made, who came down from heaven, etc. The argument can be put as follows:

$1 \mathrm{n}(\mathrm{R}) . \quad$ Christ-qua-divine is impassible. ${ }^{37}$ (Assume.)

$2 \mathrm{n}(\mathrm{R})$. Christ-qua-human is passible.

$3 \mathrm{n}(\mathrm{R})$. Christ-qua-divine is the same person as Christ-qua-human.

(Assume.)

4n. Passible and impassible are incompatible intrinsic properties.

(From IdA.)

5n. Nothing can be both passible and impassible.

(From InA.)

(From NIP and

6n(R). Christ-qua-divine is passible.

$4 \mathrm{n}$.

(From $2 \mathrm{n}(\mathrm{R})$, $3 n(R)$, and II.)

$7 \mathrm{n}(\mathrm{R}) . \quad$ Christ-qua-divine is both passible and impassible.

(From $1 n(R)$ and $6 n(R)$.

8n. Contradiction!

(From 5n and $7 \mathrm{n}(\mathrm{R})$.

On the relative identity theorist's view, the first three premises are true. And the fourth is true as well. Were the relative identity theorist to deny that the properties are incompatible, he would not need to posit relative identity, or make the second presupposition mentioned above.

Whether $5 n$ is true is tricky for the relative identity theorist. On the one hand, Christ-qua-human is (the same person as) Christ-qua-divine, and Christ-qua-human is passible, and Christ-qua-divine is impassible. So it appears that they should deny that nothing can be both passible and impassible. There's someone - the God-man - who is both. But I think the relative identity theorist will affirm this premise as well. For, again,

${ }^{37}$ Is this response really an (S) response? It is, after all, using the (S) response terminology. I think not. The (S) responses take the things named by "Christ-qua-human" and "Christ-quadivine" not to be identical. But this theory does take them to be identical, but claims that from their identity (under a sortal, of course) and from the fact that Christ-qua-divine is impassible, it doesn't follow that Christ-qua-human is impassible. 
were something able to be both passible and impassible, there would be no reason to posit something like relative identity theory.

On my reading, the relative identity theorist will grant premises $1 \mathrm{n}(\mathrm{R})$ through $5 n$. He will deny, though, the justification upon which the inference to premise $6 n(R)$ relies, on the grounds that it employs the Indiscernibility of Identicals, which is something his view, in its second presupposition, entails to be false.

This response, too, is discussed in the Christological literature. As noted above, van Inwagen works out a careful metaphysical presentation of the view. The response is criticized by Robin Le Poidevin (2009) among others, and recently defended by Christopher Conn (2012).

This response, then, sees the "qua" modifier as a sortal indicator, it denies the truth of the Indiscernibility of Identicals, and one example of it is the relative identity response.

As I stated in the introduction to this article, I know of no philosopher who employs relative identity as an answer to the problem of temporary intrinsics. It is not hard to see how such a view might go. Rather than relativizing to a natural kind, one would be relativizing to times. Louise-at- $t_{1}$ and Louise-at- $t_{2}$ are the same person - this is not the claim that they are parts of the same person, as the temporal part theorist says but they are not the same ... what? I don't think we have a good word for it. They are not the same $t_{1} e r$, maybe. It is hard to give a plausible story of how such relativizing would go, but then this is not a novel predicament for the relative identity theory. It is already a theory that requires that there could be a single person wearing two name tags:
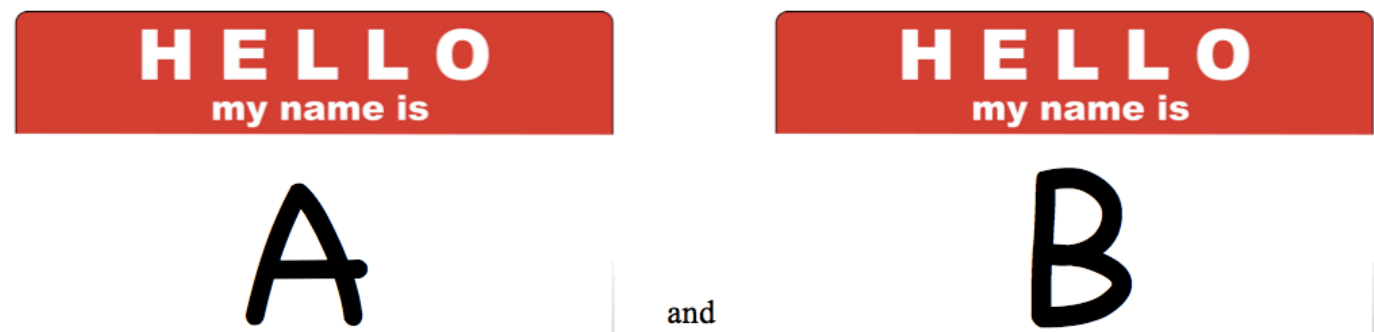

and

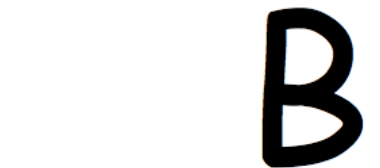

where there are some properties had by A that are not had by B. 


\section{Summary of Responses}

As before, I see three ways of dividing up the information about the responses:

by which way it understands the "qua" modification, by which premise or assumption it denies, and by which extant solutions it maps on to. Again, I will represent that information in a table:

\begin{tabular}{|l|l|l|}
\hline How "qua-N" works: & $\begin{array}{l}\text { By the Premise or inference it } \\
\text { Denies: }\end{array}$ & By the Extant Solutions: \\
\hline $\begin{array}{l}\text { It signals the tense of the } \\
\text { predication }\end{array}$ & $\begin{array}{l}\text { Revise at least one predication } \\
\text { and 7n; deny inference to 8n }\end{array}$ & Kenotic Christology \\
\hline $\begin{array}{l}\text { It modifies the assertion } \\
(\mathrm{A}): \text { "at } \mathrm{t}, \mathrm{x} \text { is F" }\end{array}$ & $\begin{array}{l}\text { Revise both predications; deny } \\
\text { inference to 6n(A) }\end{array}$ & $\begin{array}{l}\text { The analogue of Haslanger's } \\
\text { first adverbial account }\end{array}$ \\
\hline $\begin{array}{l}\text { It modifies the subject (S): } \\
\text { "x-at-t is F" }\end{array}$ & $\begin{array}{l}\text { Deny the Identity Assumption; } \\
\text { deny premise 3n }\end{array}$ & $\begin{array}{l}\text { Model A / } \\
\text { Model T }\end{array}$ \\
\hline $\begin{array}{l}\text { It modifies the predicate } \\
(\mathrm{P}): \text { " } \mathrm{x} \text { is F-at-t" }\end{array}$ & $\begin{array}{l}\text { Deny the Incompatibility } \\
\text { Assumption; deny premises } \\
\text { 4n\&5n }\end{array}$ & $\begin{array}{l}\text { Substitutional Relativizing / } \\
\text { Non-substitutional Relativizing }\end{array}$ \\
\hline $\begin{array}{l}\text { It modifies the copula (C): } \\
\text { " } \mathrm{x} \text { is-at-t } \mathrm{F} \text { " }\end{array}$ & $\begin{array}{l}\text { Deny No Incompatible } \\
\text { Properties; deny premise } 5 \mathrm{n}\end{array}$ & $\begin{array}{l}\text { Substitutional Relativizing / } \\
\text { Non-substitutional Relativizing }\end{array}$ \\
\hline It signals the tacit sortal & $\begin{array}{l}\text { Deny the Indiscernibility of } \\
\text { Identicals; deny premise 5n }\end{array}$ & Relative Identity Solutions \\
\hline
\end{tabular}

This concludes my discussion of the solutions to the problem of natural intrinsics.

\section{CONCLUSION}

In this paper I have briefly presented the problem of temporary intrinsics, along with five types of responses to the problem. I then presented the fundamental problem for Christology, which I called the problem of natural intrinsics. I presented six types of response to the problem, all but the last analogous to a response to the problem of temporary intrinsics.

My goal has not been to argue that any individual response to either problem is correct. Instead, my goal has been to present an interesting and unnoticed similarity between two different problems, and to note how work on one problem can help with work on the other. ${ }^{38}$

\footnotetext{
38 Acknowledgements XXXX.
} 


\section{BIBLIOGRAPHY}

Adams, Marilyn McCord. 2009. “Christ as God-Man, Metaphysically Construed." In Oxford Readings in Philosophical Theology, 239-263. Oxford University Press.

Bäck, Allan T. 1998. "Scotus on the Consistency of the Incarnation and the Trinity." Vivarium 36 (1): 83-107.

Bergmann, Michael, and Jeffrey E. Brower. 2006. “A Theistic Argument Against Platonism (and in Support of Truthmakers and Divine Simplicity)." Oxford Studies in Metaphysics 2: 357386.

Bohn, Einar Duenger. 2012. “The Logic of the Incarnation.” In Logic In Orthodox Christian Thinking, edited by Andrew Schumann. Gazelle Distribution.

Brower, Jeffrey E. 2008. "Making Sense of Divine Simplicity." Faith and Philosophy 25 (1): 3-30.

- - - 2009. "Simplicity and Aseity." In The Oxford Handbook of Philosophical Theology. Oxford University Press.

- - - 2011. "Aristotelian Endurantism: A New Solution to the Problem of Temporary Intrinsics." Mind 119 (476): 883-905.

Caplan, Ben. 2005. “Why So Tense About the Copula?" Mind 114 (455): 703-708.

Conn, Christopher Hughes. 2012. "Relative Identity, Singular Reference, and the Incarnation: a Response to Le Poidevin." Religious Studies 48 (01): 61-82. doi:10.1017/S0034412511000035.

Craig, William Lane. 1998. "McTaggart's Paradox and the Problem of Temporary Intrinsics." Analysis 58 (2): 122-127.

Cross, Richard. 2005. The Metaphysics of the Incarnation: Thomas Aquinas to Duns Scotus. Oxford University Press, USA.

- - - 2011. "The Incarnation." In The Oxford Handbook of Philosophical Theology, edited by Thomas P. Flint and Michael Rea, 452-475. USA: Oxford University Press.

Davis, Stephen T. 1983. Logic and the Nature of God. Palgrave MD.

- - - 1988. "Jesus Christ: Savior or Guru?" In Encountering Jesus, edited by Stephen T. Davis, 39-76. Westminster John Knox Press.

- - - 2006. "Is Kenosis Orthodox." In Exploring Kenotic Christology, edited by C. Stephen Evans, 112-138. Oxford: Oxford University Press.

- - - 2011. "The Metaphysics of Kenosis." In The Metaphysics of the Incarnation, edited by Anna Marmodoro and Jonathan Hill, 114-133. Oxford University Press, USA.

Dolezal, James E. 2011. God Without Parts: Divine Simplicity and the Metaphysics of God's Absoluteness. Pickwick Publications.

Ehring, Douglas. 1997. “Lewis, Temporary Intrinsics and Momentary Tropes.” Analysis 57 (4): 254-258.

Evans, C. Stephen. 2006. Exploring Kenotic Christology: The Self-Emptying of God. Oxford University Press.

Fiocco, M. Oreste. 2010. “Temporary Intrinsics and Relativization.” Pacific Philosophical Quarterly 91 (1): 64-77.

Flint, Thomas P. 2011. "Should Concretists Part with Mereological Models of the Incarnation?" In The Metaphysics of the Incarnation, edited by Anna Marmodoro and Jonathan Hill, 67-87. Oxford University Press, USA.

- - - 2012. "Molinism and Incarnation." In Molinism: The Contemporary Debate, edited by Ken Perszyk, 187-207. Oxford: Oxford University Press.

Forrest, Peter. 2009. "The Incarnation: A Philosophical Case for Kenosis." In Oxford Readings in Philosophical Theology, edited by Michael C. Rea, 225-238. Oxford University Press.

Hansson, Tobias. 2007. "The Problem(s) of Change Revisited." Dialectica 61 (2): 265-274.

Haslanger, Sally. 1989. "Endurance and Temporary Intrinsics." Analysis 49 (3): 119-125.

Inwagen, Peter van. 1990. "Four-Dimensional Objects." Noûs 24: 245-255.

Leftow, Brian. 2004. “A Timeless God Incarnate.” In The Incarnation, edited by Stephen T. Davis, Daniel Kendall, and Gerald O'Collins, 273-299. Oxford University Press, USA.

- - - 2011. "Composition and Christology." Faith and Philosophy 28 (3): 310-322. 
Lewis, David. 1988. “Rearrangement of Particles: Reply to Lowe.” Analysis 48 (2): 65-72.

- - . 2001. On the Plurality of Worlds. Wiley-Blackwell.

- - - 2002. "Tensing the Copula." Mind 111 (441): 1-14.

Lombard, Lawrence B. 2003. "The Lowe Road to the Problem of Temporary Intrinsics." Philosophical Studies 112 (2): 163-185.

Lowe, E. J. 1987. “Lewis on Perdurance Versus Endurance.” Analysis 47 (3) (June 1): 152-154. doi:10.2307/3328678.

- - - 1988. "The Problems of Intrinsic Change: Rejoinder to Lewis." Analysis 48 (2) (March 1): 72-77. doi:10.2307/3328772.

- - - . 2002. A Survey of Metaphysics. Oxford University Press, USA.

Mellor, D. H. 1985. Real Time. CUP Archive.

--- . 1998. Real Time II. Routledge.

Merricks, Trenton. 1994. "Endurance and Indiscernibility." Journal of Philosophy 91 (4): 165-184.

Morris, Thomas V. 1987. The Logic of God Incarnate. Cornell Univ Pr.

Oaklander, L. Nathan. 1999. “Craig on Mctaggart's Paradox and the Problem of Temporary Intrinsics." Analysis 59 (264): 314-318.

Pohle, Joseph. 1913. Christology: A Dogmatic Treatise on the Incarnation.

Poidevin, Robin le. 2009. "Identity and the Composite Christ: An Incarnational Dilemma." Religious Studies 45 (2): 167-186.

Pruss, Alexander. "On Three Problems of Divine Simplicity."

Rettler, Bradley. 2012. "McTaggart and Indexing the Copula." Philosophical Studies 158 (3): 431434.

Senor, Thomas D. 2002. “Incarnation, Timelessness, and Leibniz's Law Problems." In God and Time: Essays on the Divine Nature. Oxford University Press.

- - - 2007. "The Compositional Account of the Incarnation." Faith and Philosophy 24 (01): 52-71.

- - - . 2011. "Drawing on Many Traditions: An Ecumenical Kenotic Christology." In The Metaphysics of the Incarnation, edited by Anna Marmodoro and Jonathan Hill, 88-113. Oxford University Press, USA.

Stump, Eleonore. 2004. “Aquinas's Metaphysics of the Incarnation." In The Incarnation, edited by Stephen T. Davis, Daniel Kendall, and Gerald O'Collins, 197-218. Oxford University Press, USA.

--- . 2005. Aquinas. Routledge.

Tanner, Norman P. 1990. Decrees of the Ecumenical Councils 2 Volume Set. Georgetown University Press.

Thompson, Thomas R. 2006. "Nineteenth-Century Kenotic Christology: The Waxing, Waning, and Weighing of a Quest for a Coherent Orthodoxy." In Exploring Kenotic Christology, edited by C. Stephen Evans, 74-111. Oxford: Oxford University Press.

Van Inwagen, Peter. 1998. "Incarnation and Christology." Edited by E. Craig. Routledge Encyclopedia of Philosophy. London: Routledge. http://www.rep.routledge.com/article/K038SECT4.

Van Inwagen, Peter. 1988. "And yet There Are Not Three Gods, but One God." In .

Wasserman, R. 2003. "The Argument From Temporary Intrinsics." Australasian Journal of Philosophy 81 (3): 413-419.

Weatherson, Brian, and Dan Marshall. 2013. "Intrinsic Vs. Extrinsic Properties." In The Stanford Encyclopedia of Philosophy, edited by Edward N. Zalta, Spring 2013.

http:// plato.stanford.edu/archives/spr2013/entries/intrinsic-extrinsic/.

Zimmerman, Dean W. 2005. "The A-Theory of Time, the B-Theory of Time, and 'Taking Tense Seriously'." Dialectica 59 (4): 401-457. 